\title{
Groundwater characterization and selection of suitable water type for irrigation in the western region of Bangladesh
}

\author{
Mirza A. T. M. Tanvir Rahman • A. H. M. Saadat • \\ Md. Safiqul Islam • Md. Abdullah Al-Mansur • \\ Shamim Ahmed
}

Received: 31 May 2014/ Accepted: 16 October 2014/Published online: 13 November 2014

(C) The Author(s) 2014. This article is published with open access at Springerlink.com

\begin{abstract}
The main source of irrigation water in Bangladesh is groundwater, hence its quality needs to be ensured; otherwise, it can damage soil and reduce crop production. In current research, work by analyzing hydrogeochemical characteristics of groundwater different water types have been assessed to find out the suitable irrigation water of Godagari upazila in the western zone of Bangladesh. Studied parameters include $\mathrm{pH}, \mathrm{EC}, \mathrm{TDS}, \mathrm{K}^{+}$, $\mathrm{Na}^{+}, \mathrm{Ca}^{2+}, \mathrm{Mg}^{2+}, \mathrm{Fe}^{2+}, \mathrm{Cl}^{-}, \mathrm{Br}^{-}, \mathrm{NO}_{3}{ }^{-}$and $\mathrm{SO}_{4}{ }^{2-}$ along with sodium adsorption ratio (SAR), soluble sodium percentage (SSP), residual sodium bicarbonate (RSBC), permeability index (PI), magnesium adsorption ratio (MAR), Kelley's ratio (KR), $\mathrm{Mg}: \mathrm{Ca}$ and $\mathrm{Na}: \mathrm{Ca}$. XLSTAT and AquaChem software were used to perform factor analysis and determine water types of groundwater, respectively. The mean trends of cations and anions of the study area are $\mathrm{Na}^{+}>\mathrm{Ca}^{2+}>\mathrm{Mg}^{2+}>\mathrm{K}^{+}>\mathrm{Fe}^{2+}$ and $\mathrm{Cl}^{-}>\mathrm{HCO}_{3}{ }^{-}>$ $\mathrm{SO}_{4}{ }^{2-}>\mathrm{NO}_{3}{ }^{-}$where silicate-weathered minerals influence the groundwater quality of the study area. Except PI all parameters satisfy irrigation water standards. However, $\mathrm{Na}-\mathrm{Ca}-\mathrm{Mg}$ and $\mathrm{Na}-\mathrm{Ca}-\mathrm{Cl}$ types of water need to be under observation for any future changes since SSP is not satisfied for both of them and considering $\mathrm{KR} \mathrm{Na}-\mathrm{Ca}-\mathrm{Cl}$ water type is not suited. Except these two groups, $\mathrm{Ca}-\mathrm{Na}-\mathrm{Mg}$ and $\mathrm{Ca}-\mathrm{Na}-\mathrm{Mg}-\mathrm{Cl}$ water types are suitable for irrigation.
\end{abstract}

M. A. T. M. Tanvir Rahman ( $($ ) - A. H. M. Saadat .

Md. S. Islam

Department of Environmental Sciences, Jahangirnagar

University, Dhaka 1342, Bangladesh

e-mail: tanvir497@juniv.edu

Md. A. Al-Mansur · S. Ahmed

Analytical Research Division, Bangladesh Centre for Scientific and Industrial Research (BCSIR), Dhaka, Bangladesh
Keywords Factor analysis - Piper diagram - Rajshahi · Silicate · Wilcox's diagram

\section{Introduction}

Agriculture was entirely dependent on surface water and monsoon rainfall in Bangladesh prior to the 1970s (UNDP 1982). After that to produce high-yielding rice varieties (MPO 1987) and to achieve success the international campaign of clean drinking water decade (1980-1990), millions of drinking and irrigation water wells have been installed in Bangladesh (WARPO 2000; BGS and DPHE 2001; World Bank 2005). Now groundwater is the main source of irrigation water of Bangladesh (Shirazi et al. 2010). By 2006, nearly $78 \%$ of the irrigated rice-fields were supplied by groundwater of which about $80 \%$ of the irrigation water derived from shallow tubewells and the rest was irrigated by deep tubewells (UNDP 1982; BBS 2009). Such irrigation water needs to be of appropriate quality. The chemical constituents of irrigation water can affect plant growth directly through toxicity or deficiency, or indirectly by altering plant availability of nutrients (Ayers and Westcot 1985; Rowe and Magid 1995). Bad irrigation water not only can affect crop production, but also soil fertility that influences soil physical condition (AlOmran et al. 2010). Moreover, currently groundwater is the only limiting resource for further intensification of agriculture, therefore its rational use should be ensured in terms of quality and quantity (Sarkar and Hassan 2006). Thus, knowledge of irrigation water quality is critical to the understanding of necessarymanagement changes for longterm productivity (Bauder et al. 2004).

Water quality analysis is an important issue in groundwater studies. Quality of groundwater is equally important 
to its quality owing to the suitability of water for various purposes (Subramani et al. 2005). Many researchers reveal the groundwater quality of different regions of Bangladesh for irrigation purpose: Quddus and Zaman (1996) studied the irrigation water quality of some selected villages of Meherpur district of Bangladesh, Mridha et al. (1996) explored groundwater at Natore district, Talukder et al. (1998) worked on groundwater of Kishoreganj district, Shahidullah et al. (2000) and Sultana et al. (2009) assessed the groundwater quality in Mymensigh district, Sarkar and Hassan (2006) investigated the groundwater of Pabna district. Raihan and Alam (2008) analyzed groundwater quality throughout the Sunamganj district, Islam and Shamsad (2009) assessed groundwater quality of Bogra district and Rahman et al. (2012) studied groundwater quality of Satkhira district for irrigation purpose.

Although several research works revealed groundwater quality for irrigation purpose in the western and northwestern districts (e.g., Natore, Pabna and Bogra), investigation in other districts is also needed. This is because it was reported that in the same geographic area, groundwater composition can be varied (Sood et al. 1998). Poor-quality irrigation water reduces soil productivity, changes soil physical and chemical properties, creates crop toxicity and ultimately reduces yield (Talukder et al. 1999). Therefore, to safeguard the long-term sustainability of the groundwater resources the quality of the water needs to be continuously monitored (Raihan and Alam 2008). However, if it is possible to identify which water type(s) is suitable for irrigation in a specific area then it will be more convenient and less time consuming to identify suitability of irrigation water. In view of this, an attempt has been made to analyze the groundwater quality of the western region of Bangladesh to determine the exact level of physico-chemical parameters with special emphasis on its irrigation suitability and find out best water type to be used as irrigation water in the study area.

\section{Materials and methods}

Study area and sampling

The study was conducted at Godagari upazila under Rajshahi district of western zone of Bangladesh. Fifteen deep groundwater samples (S1-S15) were collected from 15 randomly selected irrigation pump wells whose depths varied from 110 to $185 \mathrm{~m}$ (Fig. 1). Each well was pumped until steady $\mathrm{pH}$ and electrical conductivity were obtained. Samples were collected in 500-ml polyethylene bottles. The bottles were rinsed with distilled water before collecting the sample water. From each location, two sets of samples were collected. One was non-acidified and other

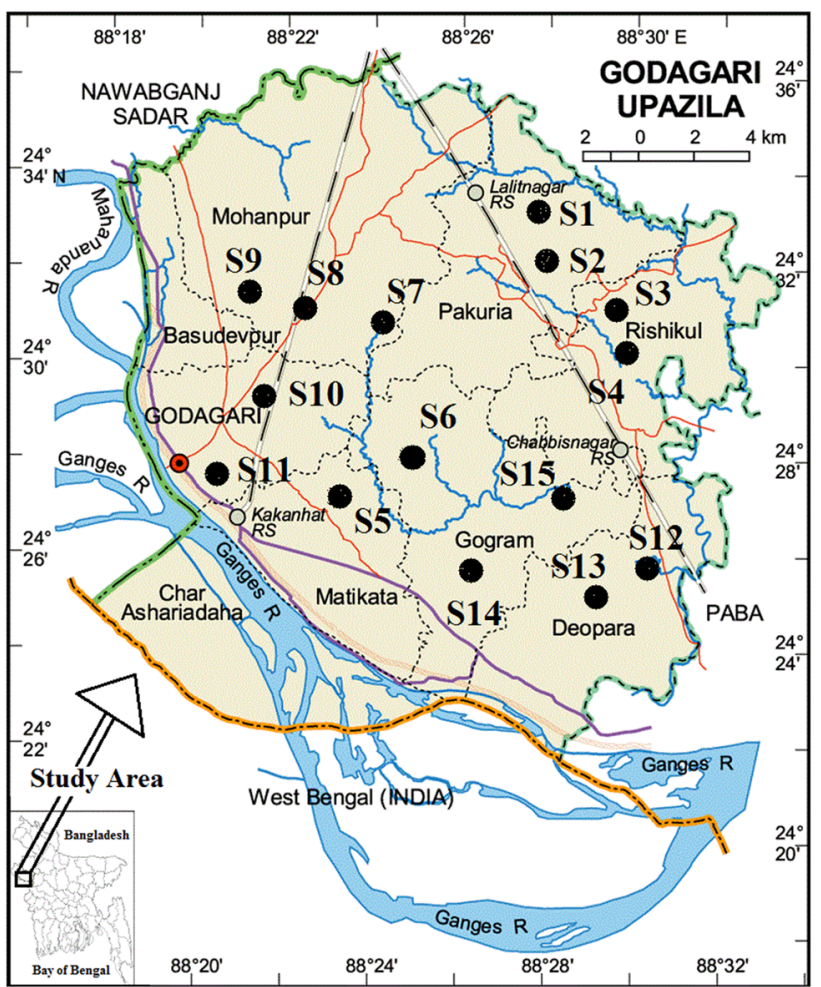

Fig. 1 Location of sampling sites in the study area

was acidified with 0.01 molar hydrochloric acid. The geographical location of each pumping well was determined with a handheld global positioning system (GPS) (Explorist 200, Megellan). Water samples were labeled and then transferred immediately to the Bangladesh centre for scientific and industrial research (BCSIR) laboratories in Dhaka, Bangladesh for chemical analysis.

Measurement of physico-chemical parameters

The $\mathrm{pH}$ and EC were determined during sampling by using EcoScan Ion 6 and Hanna HI 8633 portable meters, respectively. Each portable meters were calibrated with standard solutions according to instrument manuals. Other parameters were measured in the Bangladesh centre for scientific and industrial research (BCSIR) laboratories. Total dissolved solids (TDS) were estimated by weighing the solid residue obtained by evaporation of a measured volume of water samples to dryness (Chopra and Kanwar 1980). Potassium $\left(\mathrm{K}^{+}\right)$and sodium $\left(\mathrm{Na}^{+}\right)$were determined by flame emission spectrophotometer (Model SHIMADZU, AA-6401F) (Golterman 1971). Calcium $\left(\mathrm{Ca}^{2+}\right)$, magnesium $\left(\mathrm{Mg}^{2+}\right)$ and iron $\left(\mathrm{Fe}^{2+}\right)$ were analyzed directly by atomic absorption spectrophotometer and chloride $\left(\mathrm{Cl}^{-}\right)$, bromide $\left(\mathrm{Br}^{-}\right)$, nitrate $\left(\mathrm{NO}_{3}{ }^{-}\right)$and sulfate $\left(\mathrm{SO}_{4}{ }^{2-}\right)$ of the groundwater samples were determined by ion chromatography according to standard methods (APHA 
1998). Bicarbonate $\left(\mathrm{HCO}_{3}{ }^{-}\right)$was determined by acidimetric titration (Chopra and Kanwar 1980). The types of water have been determined by using AquaChem (version 3.6) software.

\section{Factor analysis (FA)}

Multivariate statistical methods including factor analysis (FA) have been used successfully in hydrochemistry for many years (Praus 2005). FA enables to explain the relationships among numerous important variables with a smaller set of independent variables. There are three stages in FA: for all the variables a correlation matrix is generated, factors are extracted from the correlation matrix based on the correlation coefficients of the variables to maximize the relationship between some of the factors and variables, the factors are rotated (Gupta et al. 2005). The correlation matrix is used to account for the degree of mutually shared variability between individual pairs of water quality variables. Then, eigenvalues and factor loadings for the correlation matrix are determined. Eigenvalues correspond to the eigenfactor which identifies the groups of variables that are highly correlated among them. Lower eigenvalues may contribute little to the explanatory ability of the data. Only the first few factors are needed to account for much of the parameter variability. Once the correlation matrix and eigenvalues are obtained, factor loadings are used to measure the correlation between the variables and factors. Finally factor rotation is done to facilitate interpretation by providing a simpler factor structure (Zeng and Rasmussen 2005). For current research, XLSTAT (version 2013.6.03) had been used to perform the FA.

Irrigation water quality

Use of poor water quality can create four types of problems such as toxicity, water infiltration rate, salinity and miscellaneous (Ayers and Westcot 1985). To assess water quality for irrigation, there are four most popular criteria like TDS or EC, sodium adsorption ratio (SAR), chemical concentration of elements like $\mathrm{Na}^{+}, \mathrm{Cl}^{-}$and/or $\mathrm{B}^{-}$and residual sodium carbonate (RSC) (Michael 1992; Raghunath 1987). For current irrigation water quality assessment besides the individual chemical parameters, the following parameters have been considered.

According to Richards LA (US Salinity Laboratory) (1954), sodium adsorption ratio (SAR) is expressed as:

$\mathrm{SAR}=\frac{\mathrm{Na}^{+}}{\sqrt{\left(\mathrm{Ca}^{2+}+\mathrm{Mg}^{2+}\right) / 2}}$

Todd (1980) defined soluble sodium percentage (SSP) or $\mathrm{Na}^{+} \%$ as:
$\mathrm{SSP}=\frac{\mathrm{Na}^{+}+\mathrm{K}^{+}}{\mathrm{Ca}^{2+}+\mathrm{Mg}^{2+}+\mathrm{Na}^{+}+\mathrm{K}^{+}} \times 100$

Gupta (1983) expressed residual sodium bicarbonate (RSBC) as:

$\mathrm{RSBC}=\mathrm{HCO}_{3}^{-}-\mathrm{Ca}^{2+}$

Doneen (1964) defined permeability index (PI) as:

$\mathrm{PI}=\frac{\mathrm{Na}^{+}+\sqrt{\mathrm{HCO}_{3}{ }^{-}}}{\mathrm{Ca}^{2+}+\mathrm{Mg}^{2+}+\mathrm{Na}^{+}} \times 100$

Magnesium adsorption ratio (MAR) (Raghunath 1987), also known as magnesium hazard (MH) was calculated as:

$\mathrm{MAR}=\frac{\mathrm{Mg}^{2+}}{\mathrm{Ca}^{2+}+\mathrm{Mg}^{2+}} \times 100$

Lastly, Kelley's ratio (KR) (Kelley 1963) described as:

$\mathrm{KR}=\frac{\mathrm{Na}^{+}}{\mathrm{Ca}^{2+}+\mathrm{Mg}^{2+}}$

All ionic concentrations are in milli equivalent per liter $(\mathrm{meq} / \mathrm{L})$. All these parameters and individual chemical parameters had been compared with national and international standards to assess the groundwater for suitability of irrigation.

\section{Results and discussion}

General characteristics of groundwater

General characteristics of groundwater in the study area are shown in Table 1 . The $\mathrm{pH}$ of the groundwater is slightly acidic to alkaline. Piper diagram (Piper 1944) reveals that the most of the groundwater samples (about $67 \%$ ) do not contain any dominant cation (Fig. 2). However, in case of anions $60 \%$ samples fall in chloride type considering hydrochemical facies according to Kehew (2001). The mean trends of cations and anions of the study area are $\mathrm{Na}^{+}>\mathrm{Ca}^{2+}>\mathrm{Mg}^{2+}>\mathrm{K}^{+}>\mathrm{Fe}^{2+}$ and $\mathrm{Cl}^{-}>\mathrm{HCO}_{3}{ }^{-}>$ $\mathrm{SO}_{4}{ }^{2-}>\mathrm{NO}_{3}{ }^{-}$, respectively. From the Pearson correlation matrices (Table 2) it is seen that EC and TDS, pH and $\mathrm{HCO}_{3}{ }^{-}$, and $\mathrm{Ca}^{2+}$ and $\mathrm{SO}_{4}{ }^{2-}$ have strong positive correlation. $\mathrm{Na}^{+}$and $\mathrm{Cl}^{-}, \mathrm{Ca}^{2+}$ and $\mathrm{Mg}^{2+}, \mathrm{Ca}^{2+}$ and $\mathrm{NO}_{3}{ }^{-}$, $\mathrm{Mg}^{2+}$ and $\mathrm{SO}_{4}{ }^{2-}$, and $\mathrm{Mg}^{2+}$ and $\mathrm{NO}_{3}{ }^{-}$have moderate positive correlations with each other. This means that the paired parameters have strong to moderate influence with each other. Bogra district, situated northeast of the study area, shows similar condition considering EC and TDS values. Islam and Shamsad (2009) found EC and TDS in Bogra with mean values of $549.5 \mu \mathrm{S} / \mathrm{cm}$ and $335.70 \mathrm{mg} / \mathrm{L}$ where current study shows mean values of $563.07 \mu \mathrm{S} / \mathrm{cm}$ and $320.40 \mathrm{mg} / \mathrm{L}$, respectively. 
Table 1 General characteristics of groundwater

\begin{tabular}{lrrrrr}
\hline Parameters & Minimum & Maximum & Mean & Median & $\begin{array}{r}\text { Standard } \\
\text { deviation }\end{array}$ \\
\hline $\mathrm{pH}$ & 5.70 & 8.60 & 6.89 & 6.90 & 0.86 \\
$\mathrm{EC}(\mu \mathrm{S} / \mathrm{cm})$ & 349.00 & 741.00 & 563.07 & 546.00 & 100.24 \\
$\mathrm{TDS}(\mathrm{mg} / \mathrm{L})$ & 233.00 & 399.00 & 320.40 & 322.00 & 42.74 \\
$\mathrm{Na}^{+}(\mathrm{mg} / \mathrm{L})$ & 44.37 & 129.28 & 82.97 & 85.04 & 22.52 \\
$\mathrm{~K}^{+}(\mathrm{mg} / \mathrm{L})$ & 0.72 & 1.67 & 1.20 & 1.21 & 0.27 \\
$\mathrm{Ca}^{2+}(\mathrm{mg} / \mathrm{L})$ & 54.96 & 115.73 & 74.59 & 71.26 & 18.85 \\
$\mathrm{Mg}^{2+}(\mathrm{mg} / \mathrm{L})$ & 8.39 & 23.46 & 17.35 & 18.17 & 3.87 \\
$\mathrm{Cl}^{-}(\mathrm{mg} / \mathrm{L})$ & 2.00 & 431.30 & 60.37 & 7.60 & 114.68 \\
$\mathrm{Fe}^{2+}(\mathrm{mg} / \mathrm{L})$ & 0.01 & 2.25 & 0.38 & 0.15 & 0.57 \\
$\mathrm{SO}_{4}{ }^{2-}(\mathrm{mg} / \mathrm{L})$ & 1.70 & 16.70 & 4.93 & 3.20 & 4.06 \\
$\mathrm{NO}_{3}{ }^{-}(\mathrm{mg} / \mathrm{L})$ & 0.89 & 4.60 & 2.44 & 2.00 & 1.25 \\
$\mathrm{HCO}_{3}{ }^{-}(\mathrm{mg} / \mathrm{L})$ & 3.55 & 11.27 & 6.73 & 6.95 & 2.01 \\
\hline
\end{tabular}

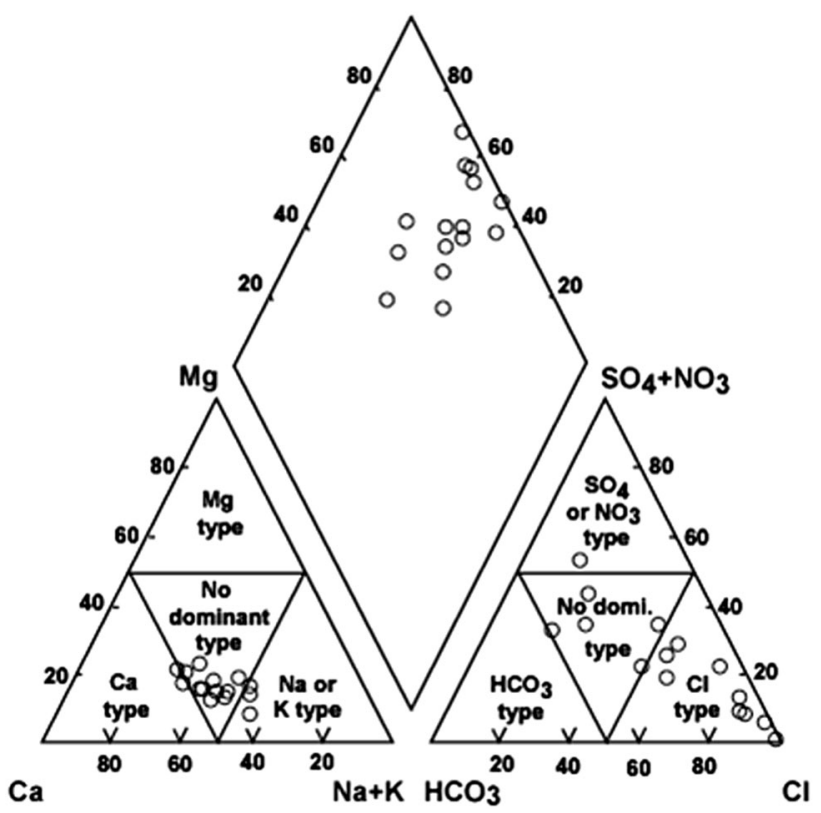

Fig. 2 Piper diagram (modified after Kehew 2001) of the chemicals in groundwater for the study area

Hydrogeochemistry of groundwater

Geochemical properties and principles that govern the behavior of dissolved chemical constituents in groundwater are referred to as hydrogeochemistry. The variation on the concentration levels of the different hydrogeochemical constituents dissolved in water determines its usefulness for domestic, industrial and agricultural purposes (Obiefuna and Sheriff 2011). Gibbs's diagrams are used to gain better insight into hydrochemical processes on groundwater chemistry in the study area (Sivasubramanian et al. 2013). Gibbs's diagrams, representing the ratios of
$\mathrm{Na}^{+}:\left(\mathrm{Na}^{+}+\mathrm{Ca}^{2+}\right)$ and $\mathrm{Cl}^{-}:\left(\mathrm{Cl}^{-}+\mathrm{HCO}_{3}{ }^{-}\right)$as a function of TDS, are widely employed to assess the functional sources of dissolved chemical constituents, such as precipitation-dominance, rock-dominance and evaporationdominance (Gibbs 1970). The chemical data of groundwater sample points of the study area are plotted in Gibbs's diagrams as shown in Fig. 3. The distribution of sample points, as shown as cluster(s), suggests that the chemical weathering of rock-forming minerals are influencing the groundwater quality.

Factor analysis (FA)

The use of factor analysis to water quality assessment has increased, mainly due to the need to obtain appreciable data reduction for analysis and decision (Chapman 1992; Kucuksezgin 1996; Chiacchio et al. 1997; Vega et al. 1998; Morales et al. 1999; Helena et al. 2000). Kaiser proposed to use only the factors with eigenvalues exceeding one (Liu et al. 2003). FA has been applied to the standardized full dataset. According to the combination of criteria for factor selection eigenvalues higher than 1.0, four most significant factors have been taken. The factor loading is classified as "strong", "moderate" and "weak" corresponding to absolute loading values of $>0.75,0.75-0.50$, and $<0.5$, respectively (Unmesh et al. 2006). Dalton and Upschurch (1978) have shown that factor scores can be related to the intensity of the particular process described. Extreme negative values (close to -1 ) indicate areas essentially unaffected by the process and the positives scores (close to $+1)$ are the areas of most affected.

Factor analysis shows that the first four factors accounted for $75.98 \%$ of the total variance whose eigenvalues is more than 1 (Table 3 ). Factor 1 (F1) shows strong loading for EC and TDS, whereas others have weak loading. This may show combined contribution of other ions in the water. Factor 2 ( $F 2$ ) shows strong loading for $\mathrm{Ca}^{2+}$ and $\mathrm{Mg}^{2+}$ which may come from silicate weathering or carbonate dissolution and also can be said as lithologically controlled. $\mathrm{SO}_{4}{ }^{2-}$ shows strong loading only in $F 2$ and $\mathrm{NO}_{3}{ }^{-}$shows moderate loading for both $F 2$ and factor 4 (F4). This may come from agricultural fertilizer indicating presence of significant anthropogenic activities in the study area. Factor 3 (F3) includes strong loading of $\mathrm{pH}$ and $\mathrm{HCO}_{3}{ }^{-}$that indicate alkaline nature of the groundwater which is also seen in the Pearson correlation matrices (Table 2).

Source rock deduction

The cations and anions are mainly derived from rock weathering rather than evaporation, crystallysation and precipitation according to Fig. 3. A major proportion of 
Table 2 Pearson correlation matrices of groundwater chemicals in the study area

\begin{tabular}{|c|c|c|c|c|c|c|c|c|c|c|c|c|}
\hline Variables & $\mathrm{EC}$ & $\mathrm{pH}$ & TDS & $\mathrm{Na}^{+}$ & $\mathrm{K}^{+}$ & $\mathrm{Ca}^{2+}$ & $\mathrm{Mg}^{2+}$ & $\mathrm{Cl}^{-}$ & $\mathrm{Fe}^{2+}$ & $\mathrm{SO}_{4}{ }^{2-}$ & $\mathrm{NO}_{3}^{-}$ & $\overline{\mathrm{HCO}_{3}{ }^{-}}$ \\
\hline $\mathrm{EC}$ & 1 & & & & & & & & & & & \\
\hline $\mathrm{pH}$ & 0.03 & 1 & & & & & & & & & & \\
\hline TDS & 0.95 & -0.01 & 1 & & & & & & & & & \\
\hline $\mathrm{Na}^{+}$ & -0.53 & -0.16 & -0.54 & 1 & & & & & & & & \\
\hline $\mathrm{K}^{+}$ & -0.21 & 0.13 & -0.35 & 0.003 & 1 & & & & & & & \\
\hline $\mathrm{Ca}^{2+}$ & 0.12 & -0.40 & 0.13 & 0.16 & 0.35 & 1 & & & & & & \\
\hline $\mathrm{Mg}^{2+}$ & 0.26 & -0.23 & 0.29 & -0.08 & 0.40 & 0.64 & 1 & & & & & \\
\hline $\mathrm{Cl}^{-}$ & -0.54 & -0.01 & -0.55 & 0.59 & 0.30 & 0.29 & 0.26 & 1 & & & & \\
\hline $\mathrm{Fe}^{2+}$ & 0.40 & 0.29 & 0.40 & -0.05 & -0.37 & -0.25 & 0.01 & -0.11 & 1 & & & \\
\hline $\mathrm{SO}_{4}^{2-}$ & 0.05 & -0.22 & 0.09 & 0.33 & 0.25 & 0.85 & 0.52 & 0.20 & -0.24 & 1 & & \\
\hline $\mathrm{NO}_{3}^{-}$ & 0.10 & -0.11 & 0.16 & 0.07 & -0.08 & 0.57 & 0.50 & 0.27 & 0.45 & 0.47 & 1 & \\
\hline $\mathrm{HCO}_{3}$ & 0.10 & 0.87 & 0.05 & -0.23 & 0.31 & -0.07 & -0.01 & 0.03 & 0.21 & 0.12 & 0.08 & 1 \\
\hline
\end{tabular}

Fig. 3 Gibbs's diagrams for groundwater of the study area
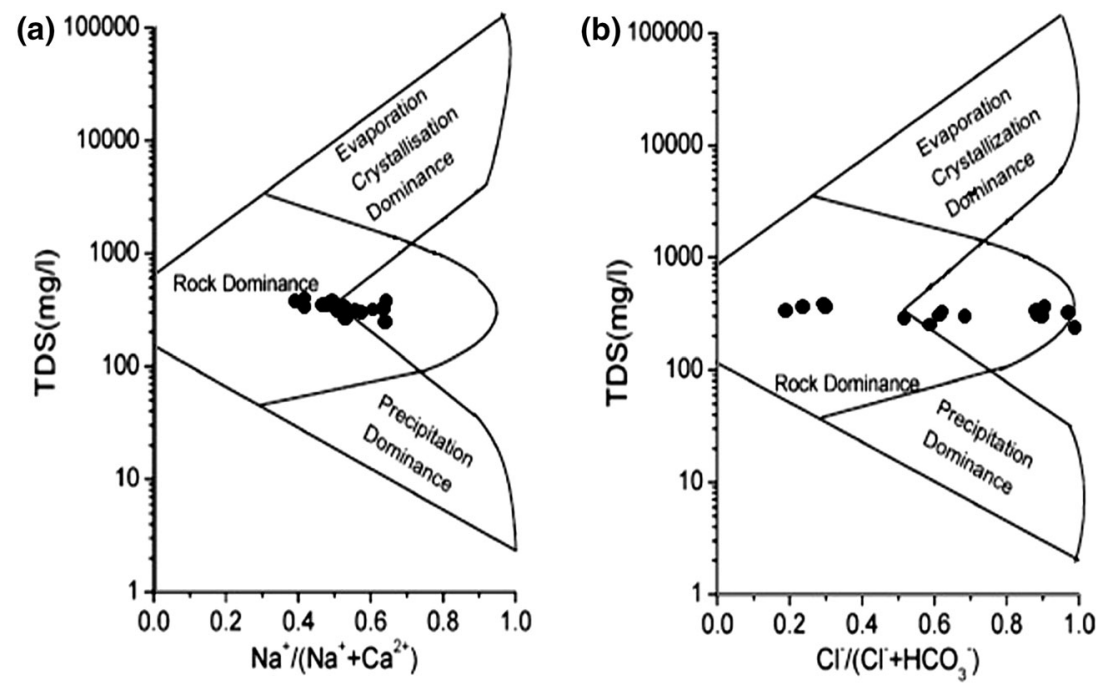

these ions can be derived from the weathering of crystalline dolomitic limestones and calcicum-magnesium silicates, chiefly from calcite, gypsum and feldspars plagioclase (Wen et al. 2005). Both $\mathrm{Ca}^{2+}$ and $\mathrm{Mg}^{2+}$ may react with $\mathrm{HCO}_{3}{ }^{-}$precipitating as calcite and dolomite. As $\mathrm{Ca}^{2+}$ and $\mathrm{Mg}^{2+}$ react with $\mathrm{HCO}_{3}{ }^{-}$there would be straight positive correlation between $\mathrm{Ca}^{2+} / \mathrm{HCO}_{3}{ }^{-}$and $\mathrm{Mg}^{2+} / \mathrm{HCO}_{3}{ }^{-}$ratios (Zahid et al. 2008). Although current study shows good positive correlation between $\mathrm{Ca}^{2+} / \mathrm{HCO}_{3}{ }^{-}$vs. $\mathrm{Mg}^{2+}$ / $\mathrm{HCO}_{3}{ }^{-}\left(r^{2}=0.72\right)$, calcite and dolomite have difficulty in forming when TDS values are less than $600 \mathrm{mg} / \mathrm{L}$ (Zhang et al. 2007). Average TDS (320.40 mg/L) is much lower than the required value; therefore in the study area it may not possible to have calcite and dolomite dissolution. Moreover if $\mathrm{Ca}^{2+}$ and $\mathrm{Mg}^{2+}$ originate only from the dissolution of carbonates in the aquifer materials and from the weathering of accessory pyroxene or amphibole minerals, then the $\left(\mathrm{Ca}^{2+}+\mathrm{Mg}^{2+}\right) / \mathrm{HCO}_{3}{ }^{-}$ratio would be 0.5 (Sami
1992). However, Fig. 4a shows the ratio is very higher than 0.5 (or 1:2 line), i.e., above 2:1 line.

In Fig. 4b, the plot of $\left(\mathrm{Ca}^{2+}+\mathrm{Mg}^{2+}\right)$ vs. $\left(\mathrm{HCO}_{3}{ }^{-}+\mathrm{SO}_{4}{ }^{2-}\right)$ shows that most of the data falls below the $1: 1$ line that reflects the requirement of cations from weathering of silicate rocks. The high ratio from Fig. 4a suggests that the excess of alkalinity of these water is balanced by alkalis, i.e., $\mathrm{Na}^{+}$and $\mathrm{K}^{+}$. Moreover, the excess of alkaline earth elements $\left(\mathrm{Ca}^{2+}\right.$ and $\left.\mathrm{Mg}^{2+}\right)$ reflects an extra source of $\mathrm{Ca}^{2+}$ and $\mathrm{Mg}^{2+}$ and is balanced by $\mathrm{Cl}^{-}$and $\mathrm{SO}_{4}{ }^{2-}$ (Wen et al. 2005). This statement is supported by Fig. 4c where $\left(\mathrm{Ca}^{2+}+\mathrm{Mg}^{2+}\right)$ vs. total cation shows that the data is below the $1: 1$ line, reflect an increasing contribution of $\mathrm{Na}^{+}$and $\mathrm{K}^{+}$as TDS increase as reported by Rahman et al. (2011).

The $\mathrm{Na}^{+}$dominance, an index of weathering, suggests that the ions result from silicate weathering or dissolution of soil salts, whereas the excess of $\left(\mathrm{Na}^{+}+\mathrm{K}^{+}\right)$over $\mathrm{Cl}^{-}$ 
Table 3 Factor pattern after Varimax rotation for the study area

\begin{tabular}{lrrrr}
\hline & \multicolumn{1}{c}{$\boldsymbol{F 1}$} & \multicolumn{1}{c}{$\boldsymbol{F 2}$} & \multicolumn{1}{c}{$\boldsymbol{F 3}$} & \multicolumn{1}{c}{$\boldsymbol{F 4}$} \\
\hline $\mathrm{EC}$ & $\mathbf{0 . 8 8 2}$ & 0.187 & 0.022 & 0.250 \\
$\mathrm{pH}$ & 0.026 & -0.259 & $\mathbf{0 . 8 8 0}$ & 0.104 \\
$\mathrm{TDS}$ & $\mathbf{0 . 9 1 9}$ & 0.209 & -0.050 & 0.322 \\
$\mathrm{Na}^{+}$ & -0.684 & 0.115 & -0.174 & 0.091 \\
$\mathrm{~K}^{+}$ & -0.196 & 0.348 & 0.322 & -0.484 \\
$\mathrm{Ca}^{2+}$ & -0.040 & $\mathbf{0 . 9 6 9}$ & -0.159 & -0.133 \\
$\mathrm{Mg}^{2+}$ & 0.112 & $\mathbf{0 . 7 4 2}$ & -0.010 & 0.009 \\
$\mathrm{Cl}^{-}$ & -0.706 & 0.306 & 0.073 & 0.031 \\
$\mathrm{Fe}^{2+}$ & 0.172 & -0.080 & 0.207 & $\mathbf{0 . 8 9 1}$ \\
$\mathrm{SO}_{4}{ }^{2-}$ & -0.092 & $\mathbf{0 . 7 9 6}$ & -0.018 & -0.094 \\
$\mathrm{NO}_{3}{ }^{-}$ & -0.099 & 0.632 & 0.013 & 0.546 \\
$\mathrm{HCO}_{3}{ }^{-}$ & 0.080 & 0.090 & $\mathbf{0 . 9 9 3}$ & 0.008 \\
$\mathrm{Variability}(\%)^{2}$ & 22.472 & 24.257 & 16.424 & 12.828 \\
$\mathrm{Cumulative}(\%)^{2}$ & 22.472 & 46.729 & 63.153 & 75.981 \\
\hline $\mathrm{Bu}^{2}$ & & &
\end{tabular}

Bold numbers indicate strong loading, italic numbers indicate moderate loading

(Fig. 4d) in the water reflects silicate weathering (Stallard and Edmond 1983) and also suggests that the higher concentration of alkalis is from the sources other than precipitation (Singh and Hasnain 1999). Additionally, the molar ratio of $\mathrm{Na}^{+} / \mathrm{Cl}^{-}>1$ (Fig. 4e) indicates the source of $\mathrm{Na}^{+}$is silicate weathering, particularly Na-plagioclase (Hounslow 1995). However, groundwater in the area have a higher ratio (average of 0.6$)$ of $\left(\mathrm{Na}^{+}+\mathrm{K}^{+}\right)$vs. total cations (Fig. 4f), depicting the contribution of cations via silicate weathering and soils, to some extent (Sarin et al. 1989; Datta and Tyagi 1996). This high ratio also shows that silicate minerals might come into the solution by the dissolution of plagioclase (albite) to kaolinite, montmorillonite and/or gibbsite according to Eqs. 7, 8 and 9, respectively (Rahman et al. 2011).

$$
\begin{aligned}
& 2 \mathrm{NaAlSi}_{3} \mathrm{O}_{8}+\underset{\text { Albite }}{2 \mathrm{CO}_{2}}+11 \mathrm{H}_{2} \mathrm{O}= \\
& \mathrm{Al}_{2} \mathrm{Si}_{2} \mathrm{O}_{5}(\mathrm{OH})_{4}+\underset{\text { Kaolinite }}{2 \mathrm{Na}^{+}}+\underset{\mathrm{HCO}_{3}^{-}}{4}+4 \mathrm{H}_{4} \mathrm{SiO}_{4} \\
& 2 \mathrm{NaAlSi}_{3} \mathrm{O}_{8}+\underset{\text { Albite }}{\mathrm{Mg}^{2+}}+4 \mathrm{H}_{2} \mathrm{O}= \\
& 2 \mathrm{Na}_{0.5} \mathrm{Al}_{1.5} \mathrm{Mg}_{0.5} \mathrm{Si}_{4} \mathrm{O}_{10}(\mathrm{OH})_{2}+2 \mathrm{Na}^{+}+\mathrm{H}_{4} \mathrm{SiO}_{4} \\
& 2 \mathrm{NaAlSi}_{3} \mathrm{O}_{8}+\underset{\text { Albite }}{\mathrm{CO}_{2}}+8 \mathrm{H}_{2} \mathrm{O}= \\
& \mathrm{Al}(\mathrm{OH})_{3}+\mathrm{Na}^{+}+\mathrm{HCO}_{3}^{-}+3 \mathrm{H}_{4} \mathrm{SiO}_{4}
\end{aligned}
$$

The Na-normalized (Gaillardet et al. 1999) ratios for $\mathrm{Ca}^{2+}$ and $\mathrm{Mg}^{2+}$ might have related to each other. Accordingly, in the plot of the molar ratios of $\mathrm{Mg}^{2+} / \mathrm{Na}^{+}$ vs. $\mathrm{Ca}^{2+} / \mathrm{Na}^{+}$are shown in a log-log plot in Fig. 5a. Recharging water flowing through carbonate-rich aquifer shows high $\mathrm{Ca}^{2+} / \mathrm{Na}^{+}$and $\mathrm{Mg}^{2+} / \mathrm{Na}^{+}$ratios. The end member having lower Na-normalized ratio is that of water draining silicates (Rahman et al. 2011). The molar $\mathrm{Ca}^{2+}$ / $\mathrm{Na}^{+}$ratio of average crustal continental rocks is close to 0.6 (Taylor and McLennan 1985), and due to higher solubility of $\mathrm{Na}^{+}$relative to $\mathrm{Ca}^{2+}$, lower $\mathrm{Ca}^{2+} / \mathrm{Na}^{+}$molar ratio is expected in groundwater, which is related to weathering of silicates. In Fig. 5a, the observed groundwater with low $\mathrm{Ca}^{2+} / \mathrm{Na}^{+}$molar ratio is being influenced by silicate weathering rather than carbonate dissolution. Similarly, in the plot for $\mathrm{Ca}^{2+} / \mathrm{Na}^{+}$vs. $\mathrm{HCO}_{3}{ }^{-}$/ $\mathrm{Na}^{+}$molar ratios (Fig. 5b), low molar ratios of them is the indication of silicate weathering.

Four water types have been found in the study area and depending on these the sample water has been divided into four groups: group $1(G 1)$ includes S1, S4, S7, S8, S9 samples that represent $\mathrm{Ca}-\mathrm{Na}-\mathrm{Mg}$ type of water; group 2 (G2) consists of S3, S5, S6, S10 for $\mathrm{Na}-\mathrm{Ca}-\mathrm{Mg}$; group 3 (G3) contains $\mathrm{S} 12, \mathrm{~S} 13, \mathrm{~S} 14, \mathrm{~S} 15$ for $\mathrm{Ca}-\mathrm{Na}-\mathrm{Mg}-\mathrm{Cl}$ and finally group $4(G 4)$ comprises $\mathrm{S} 2, \mathrm{~S} 11$ for $\mathrm{Na}-\mathrm{Ca}-\mathrm{Cl}$ water. $G 1$ shows maximum values of $\mathrm{pH}$ (7.3), EC $(602.6 \mu \mathrm{S} / \mathrm{cm})$, TDS $(339 \mathrm{mg} / \mathrm{L})$ and $\mathrm{HCO}_{3}{ }^{-}(7.26 \mathrm{mg} / \mathrm{L})$ among all groups (Table 4). G3 presents highest values of $\mathrm{Ca}^{2+}(100.73 \mathrm{mg} / \mathrm{L}), \mathrm{Mg}^{2+}(20.02 \mathrm{mg} / \mathrm{L}), \mathrm{SO}_{4}{ }^{2-}(10.3 \mathrm{mg} /$ L) and $\mathrm{NO}_{3}{ }^{-}(3.41 \mathrm{mg} / \mathrm{L}) . \mathrm{Na}^{+}$and $\mathrm{Cl}^{-}$ions show exceptionally high concentration (117.12 and $237 \mathrm{mg} / \mathrm{L}$, respectively), in $G 4$ among all groups. Individually no parameters exceed the irrigation water standards set by national and international organizations (Table 4).

TDS is an important parameter to be considered as irrigation water quality, because many of the toxic solid materials may be imbedded in the water, which may cause harm to the plants (Matthess 1982). In the absence of non-ionic dissolved constituents, TDS and EC are indicative of saline water (Michael 1992). According to Robinove et al. (1958), all samples are non-saline $(<1,000 \mathrm{mg} / \mathrm{L})$ which is suitable for irrigation. Again in terms of 'Degree of restrictions on use', TDS values $<450 \mathrm{mg} / \mathrm{L}$ represent the irrigation water as 'none' (UCCC 1974) which is met by the study area.

The sodium adsorption ratio (SAR) is generally considered an effective evaluation index for most water used in irrigated agriculture (Ayers and Westcot 1985). There is a significant relationship between SAR values of irrigation water and the extent to which $\mathrm{Na}^{+}$is absorbed by the soil (Raihan and Alam 2008). If water used for irrigation is high in $\mathrm{Na}^{+}$and low in $\mathrm{Ca}^{2+}$, the cation change complex may become saturated with $\mathrm{Na}^{+}$. This can destroy the soil structure owing to dispersion of the clay particles (Todd 1980). Presence of $\mathrm{Na}^{+}$in irrigation water reacts with soil to reduce permeability and its repeated uses makes the soil impermeable, while high $\mathrm{Na}^{+}$leads to development of alkali soil. High $\mathrm{Na}^{+}$saturation also directly causes $\mathrm{Ca}^{2+}$ deficiency. Frequent irrigation with high $\mathrm{Na}^{+}$water for a 
Fig. 4 Bivariate plots of

(a) $\mathrm{Ca}^{2+}+\mathrm{Mg}^{2+}$ vs. $\mathrm{HCO}_{3}{ }^{-}$,

(b) $\mathrm{Ca}^{2+}+\mathrm{Mg}^{2+}$ vs.

$\mathrm{HCO}_{3}{ }^{-}+\mathrm{SO}_{4}{ }^{2-}$,

(c) $\mathrm{Ca}^{2+}+\mathrm{Mg}^{2+}$ vs. total

cation, (d) $\mathrm{Na}^{+}+\mathrm{K}^{+}$vs. $\mathrm{Cl}^{-}$,

(e) $\mathrm{Na}^{+}$vs. $\mathrm{Cl}^{-}$and

(f) $\mathrm{Na}^{+}+\mathrm{K}^{+}$vs. total cation
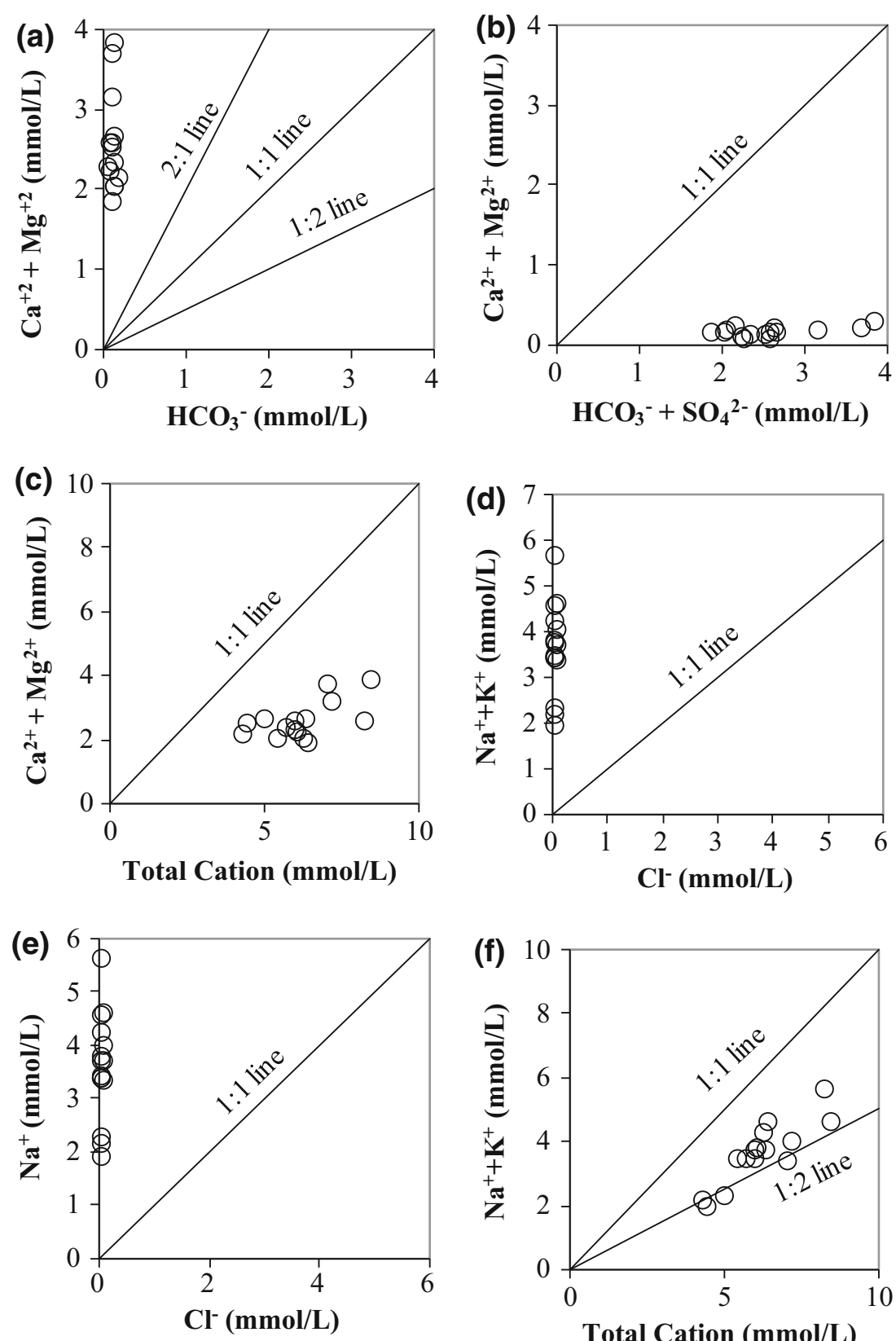

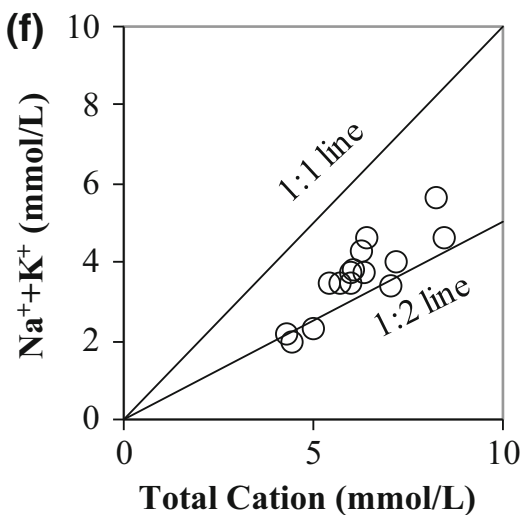

considerable duration makes the soil plastic and sticky in wet condition and form clods and crust on drying condition. In contrast, presence of $\mathrm{Ca}^{2+}$ or $\mathrm{Mg}^{2+}$ salts in irrigation water retards the evil effect of sodium by increasing the permeability of the soils (Punmia and Lal 1981; Asaduzzaman 1985). In the study area, highest SAR value is 3.42 found for $G 4$ where concentration of $\mathrm{Na}^{+}(117.12 \mathrm{mg} /$ L) is also highest among all groups and the values are within standard limits with excellent suitability for irrigation (Tables 4 and 6). Irrigation water can also be classified according to the US salinity laboratory's diagram (Richards LA (US Salinity Laboratory) 1954) where SAR is an index of sodium hazard and EC is an index of salinity hazard (Fig. 6). In this diagram all sample water shows low sodium hazard and except about $13 \%$ sample, the rest shows medium salinity hazard. Again, considering soluble sodium percentage (SSP) values suitability varies from Good ( $G 1$ and $G 3$ ) to Fair ( $G 2$ and $G 4$ ) according to Wilcox (1955) (Tables 5 and 6). More elaborately, Wilcox's diagram (Wilcox 1948) reveals that only two samples from $G 2$ and $G 4$ are Fair and other samples are classified as Good (Fig. 7). Such high SSP in irrigation water may stunt the plant growth and reduces soil permeability (Joshi et al. 2009).

$\mathrm{Fe}^{2+}$ contents of water samples were found within the safe limit for irrigation where the recommended limit of 
Fig. 5 Bivariate plots of (a) $\mathrm{Mg}^{2+} / \mathrm{Na}^{+}$vs. $\mathrm{Ca}^{2+} / \mathrm{Na}^{+}$ and (b) $\mathrm{Ca}^{2+} / \mathrm{Na}^{+}$vs. $\mathrm{HCO}_{3}{ }^{-} /$ $\mathrm{Na}^{+}$

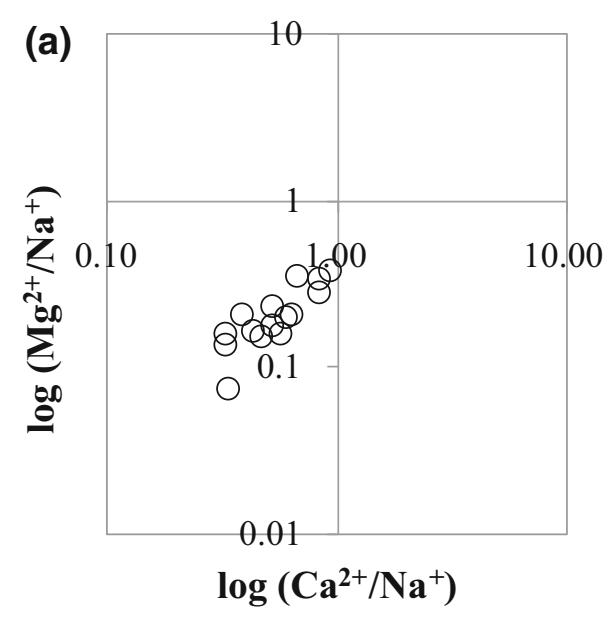

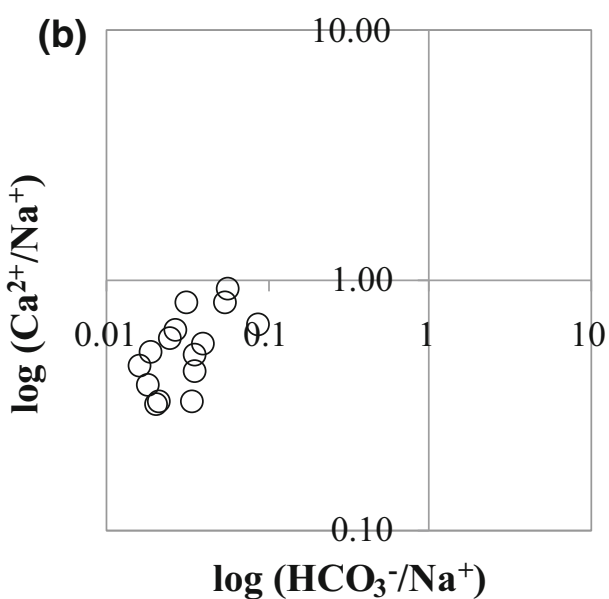

Table 4 Average values of the parameters of the study area comparing with different irrigation water standards

\begin{tabular}{|c|c|c|c|c|c|c|c|c|}
\hline \multirow[t]{2}{*}{ Parameters } & \multicolumn{4}{|c|}{ Groups of the study area } & \multicolumn{4}{|l|}{ Standards } \\
\hline & $G 1$ & $G 2$ & $G 3$ & G4 & DoE (1997) & BWPCB (1976) & UCCC (1974) & FAO (1985) \\
\hline $\mathrm{pH}$ & 7.3 & 6.6 & 6.53 & 7.2 & $6.5-8.5$ & $6.5-89.2$ & $6.5-8.4$ & $6.0-8.5$ \\
\hline $\mathrm{EC}(\mu \mathrm{S} / \mathrm{cm})$ & 602.6 & 553.75 & 590.25 & 428.5 & 2,250 & & $700-3,000$ & 3,000 \\
\hline TDS (mg/L) & 339 & 315 & 327.25 & 271 & 2,100 & 1,500 & $450-2,000$ & 2,000 \\
\hline $\mathrm{Na}^{+}(\mathrm{mg} / \mathrm{L})$ & 60.59 & 87.01 & 89.84 & 117.12 & & & 68-204 & 900 \\
\hline $\mathrm{K}^{+}(\mathrm{mg} / \mathrm{L})$ & 1.27 & 1.04 & 1.33 & 1.08 & & & & 2 \\
\hline $\mathrm{Ca}^{2+}(\mathrm{mg} / \mathrm{L})$ & 68.8 & 59.86 & 100.73 & 66.28 & & & & 400 \\
\hline $\mathrm{Mg}^{2+}(\mathrm{mg} / \mathrm{L})$ & 17.86 & 15.84 & 20.02 & 13.75 & & & & 60 \\
\hline $\mathrm{Fe}^{2+}(\mathrm{mg} / \mathrm{L})$ & 0.389 & 0.662 & 0.180 & 0.207 & & & & \\
\hline $\mathrm{Cl}^{-}(\mathrm{mg} / \mathrm{L})$ & 4.86 & 6.33 & 95.5 & 237 & 600 & 600 & 133 & 1,100 \\
\hline $\mathrm{SO}_{4}^{2-}(\mathrm{mg} / \mathrm{L})$ & 2.52 & 2.91 & 10.3 & 4.23 & & 400 & & 1,000 \\
\hline $\mathrm{NO}_{3}{ }^{-}(\mathrm{mg} / \mathrm{L})$ & 2.08 & 2.14 & 3.41 & 2.01 & 10 & 45 & 5 & 10 \\
\hline $\mathrm{HCO}_{3}{ }^{-}(\mathrm{mg} / \mathrm{L})$ & 7.26 & 5.87 & 7.11 & 6.41 & & & 91 & 600 \\
\hline
\end{tabular}

$\mathrm{Fe}^{2+}$ is $5.0 \mathrm{mg} / \mathrm{L}$ (Ayers and Westcot 1985). Total hardness (TH) of the study area varies from 214.46 to $333.63 \mathrm{mg} / \mathrm{L}$ of $\mathrm{CaCO}_{3}$ (Table 5). According to Sawyer and McCarty (1967), G3 water group belongs to very hard water $\left(>300 \mathrm{mg} / \mathrm{L}\right.$ of $\left.\mathrm{CaCO}_{3}\right)$ class and other groups are classified as hard water (150-300 mg/L of $\left.\mathrm{CaCO}_{3}\right)$. Gupta (1983) suggested that residual sodium carbonate (RSC) should be calculated simply as residual sodium bicarbonate (RSBC). The water containing $\mathrm{RSBC}<5,5-10$ and $>10 \mathrm{meq} / \mathrm{L}$ should be tentatively considered as safe, marginal and unsatisfactory, respectively (Gupta and Gupta 1987). Therefore, RSBC of the study area meets irrigation water quality where all RSBC values are $<5 \mathrm{meq} / \mathrm{L}$. RSBC indicates the excess concentration of $\mathrm{HCO}_{3}{ }^{-}$over $\mathrm{Ca}^{2+}$ (Hussain and Hussain 2004). The negative values (Table 5) of all water groups of the study area reveal excess $\mathrm{HCO}_{3}{ }^{-}$ in water. However, considering permeability index (PI) groundwater of the study area does not satisfy for irrigation. According to Donen's chart PI should be less than 1
(Raghunath 1987) where the lowest PI value of the study area is 39.2 for $G 1$ (Table 5).

Kelley's ratio (KR) indicates balance among $\mathrm{Na}^{+}, \mathrm{Ca}^{2+}$ and $\mathrm{Mg}^{2+}$ ions in water. $\mathrm{KR}$ of more than 1 indicates an excess level of $\mathrm{Na}^{+}$in water. Kelley (1963) suggested that the ratio for irrigation water should not exceed 1 . Only $G 4$ water exceeds such standard (Table 5). Magnesium adsorption ratio (MAR) causes harmful effect to soil when it exceeds 50 (Gupta and Gupta 1987). Highest MAR observed in the study area is 30.39 for $G 2$ that ensures no such effect to soil. Moreover, at the same level of salinity and SAR, adsorption of $\mathrm{Na}^{+}$by soil and clay minerals is more at higher $\mathrm{Mg}$ : $\mathrm{Ca}$ ratio. Because the bonding energy of $\mathrm{Mg}^{2+}$ is less than that of $\mathrm{Ca}^{2+}$ that allows more $\mathrm{Na}^{+}$ adsorption and it happens when the ratio exceeds 4 (Michael 1992). Richards LA (US Salinity Laboratory) (1954) named this ratio as magnesium hazard (MH). Additionally, soil containing high levels of exchangeable $\mathrm{Mg}^{2+}$ causes infiltration problem (Ayers and Westcot 


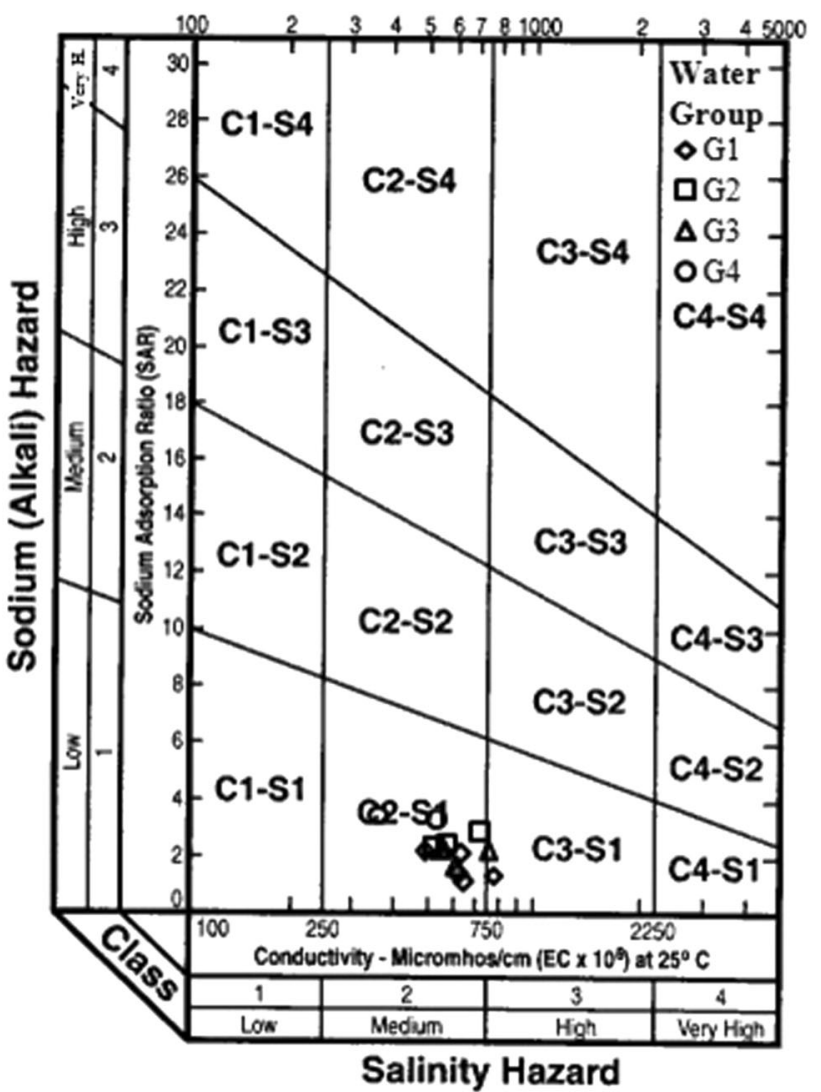

Fig. 6 US salinity laboratory's diagram for groundwater of the study area

1985). The study area have low $\mathrm{Mg}$ : Ca ratios than 4 (Table 5) that shows no threat of infiltration problem for soil from the groundwater. Similar to $\mathrm{Mg}: \mathrm{Ca}$ ratio, $\mathrm{Na}: \mathrm{Ca}$ ratio also indicates possible threat to infiltration problem arising from used irrigation water. Presence of excessive $\mathrm{Na}^{+}$in irrigation water promotes soil dispersion and structural break down when $\mathrm{Na}$ :Ca ratio exceeds 3. Infiltration problem will occur from such high ratio primarily due to lack of sufficient $\mathrm{Ca}^{2+}$ to counter the dispersing effect of $\mathrm{Na}^{+}$. Excessive $\mathrm{Na}^{+}$also create problems in crop water uptake, poor seedling emergence, lack of aeration, plant and root diseases, etc. (Ayers and Westcot 1985). Present study area has $\mathrm{Na}: \mathrm{Ca}$ ratio less than 3 (Table 5) which demonstrates that there is no possibility of infiltration problem occurring in the groundwater. Considering
Table 6 Limits of some important parameter indices for rating groundwater quality and its suitability in irrigation use

\begin{tabular}{lllll}
\hline Category & \multicolumn{2}{l}{ Groundwater quality indices* } & Suitable for irrigation \\
\cline { 2 - 4 } & EC $(\mu \mathrm{S} / \mathrm{cm})$ & SAR & SSP & \\
\hline I & $<700$ & $<10$ & $<20$ & Excellent \\
II & $700-3,000$ & $10-18$ & $20-40$ & Good \\
III & $>3,000$ & $18-26$ & $40-80$ & Fair \\
IV & - & $>26$ & $>80$ & Poor
\end{tabular}

* According to Ayers and Westcot (1985), Todd (1980) and Wilcox (1955), respectively

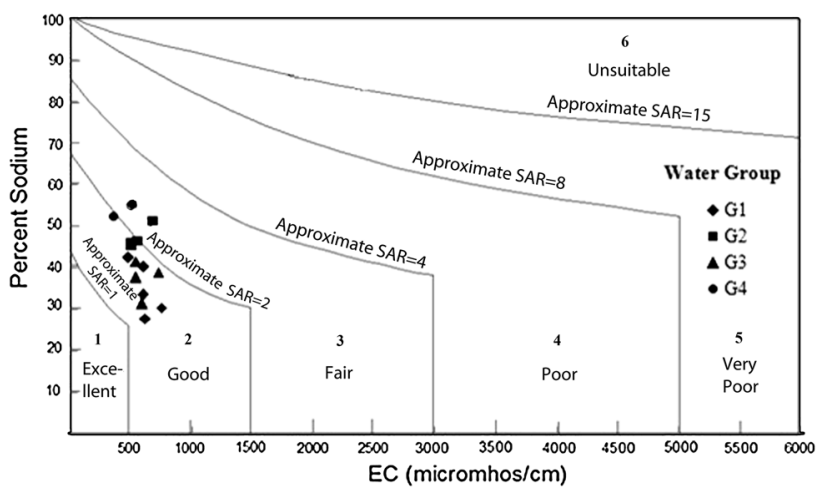

Fig. 7 Wilcox's diagram for groundwater of the study area

$\mathrm{pH}, \mathrm{EC}, \mathrm{SAR}$ and TH the groundwater of the study area is suitable for irrigation as found in Pabna district (Sarkar and Hassan 2006) and Bogra district (Islam and Shamsad 2009) which are situated at the southeast and northeast of the study area, respectively. Although in these studies KR and SSP are found to be suitable for irrigation, current research does not reveal suitability for all water types.

\section{Conclusion}

Although the mean trend of cations of the study area is $\mathrm{Na}^{+}>\mathrm{Ca}^{2+}>\mathrm{Mg}^{2+}>\mathrm{K}^{+}>\mathrm{Fe}^{2+}$, most of the groundwater samples do not contain any dominant cation. Again anions' mean trend is $\mathrm{Cl}^{-}>\mathrm{HCO}_{3}{ }^{-}>\mathrm{SO}_{4}{ }^{2-}>\mathrm{NO}_{3}{ }^{-}$ and $60 \%$ samples fall in chloride type considering hydrochemical facies. The groundwater quality in the study

Table 5 Group-wise irrigation water quality parameters of the study area

\begin{tabular}{|c|c|c|c|c|c|c|c|c|c|c|c|c|}
\hline Group ID & $\mathrm{pH}$ & $\mathrm{EC}(\mu \mathrm{S} / \mathrm{cm})$ & TDS (mg/L) & SAR & SSP & RSBC (meq/L) & PI & $\mathrm{TH}\left(\mathrm{mg} / \mathrm{L}\right.$ of $\left.\mathrm{CaCO}_{3}\right)$ & MAR & $\mathrm{KR}$ & $\mathrm{Mg}: \mathrm{Ca}$ & $\mathrm{Na}: \mathrm{Ca}$ \\
\hline$G 1$ & 7.3 & 602.6 & 339 & 1.69 & 34.85 & -3.31 & 39.2 & 245.11 & 30.04 & 0.54 & 0.43 & 0.77 \\
\hline$G 2$ & 6.6 & 553.75 & 315 & 2.57 & 47 & -2.89 & 50.62 & 214.46 & 30.39 & 0.88 & 0.44 & 1.28 \\
\hline$G 3$ & 6.53 & 590.25 & 327.25 & 2.15 & 37.31 & -4.91 & 40.38 & 333.63 & 24.51 & 0.6 & 0.33 & 0.79 \\
\hline$G 4$ & 7.2 & 428.5 & 271 & 3.42 & 53.77 & -3.2 & 57.07 & 221.88 & 24.5 & 1.16 & 0.33 & 1.54 \\
\hline
\end{tabular}


area is influenced by silicate-weathered minerals. Except PI all individual chemical parameters and $\mathrm{pH}, \mathrm{EC}, \mathrm{TDS}$, RSBC, MAR, Mg:Ca and $\mathrm{Na}: \mathrm{Ca}$ of the groundwater are satisfied as the irrigation water. Among four water types, $\mathrm{Na}-\mathrm{Ca}-\mathrm{Cl}$ type of water does not satisfy SSP and KR criteria and $\mathrm{Na}-\mathrm{Ca}-\mathrm{Mg}$ does not satisfy SSP. Therefore, these two water types are required to be monitored for future chemical status change. Other two groups, i.e., $\mathrm{Ca}-$ $\mathrm{Na}-\mathrm{Mg}$ and $\mathrm{Ca}-\mathrm{Na}-\mathrm{Mg}-\mathrm{Cl}$ water types are suitable to be used for irrigation.

Open Access This article is distributed under the terms of the Creative Commons Attribution License which permits any use, distribution, and reproduction in any medium, provided the original author(s) and the source are credited.

\section{References}

Al-Omran AM, Al-Harbi AR, Wahb-Allah MA, Nadeem M, Al-Eter A (2010) Impact of irrigation water quality, irrigation systems, irrigation rates and soil amendments on tomato production in sandy calcareous soil. Turkish J Agric For 34:59-73

APHA (1998) Standard methods for the examination of water and wastewater, American public health association. Port City Press, Maryland

Asaduzzaman M (1985) Handbook of groundwater and wells. BRAC Prokashana, Dhaka

Ayers RS, Westcot DW (1985) Water quality for agriculture, irrigation and drainage (Paper No. 29). FAO, Rome

Bauder TA, Cardon GE, Waskam RM, Davis JG (2004) Irrigation water quality-cooperative extension agriculture 506. Colorado State University, Colorado

BBS (2009) Annual agricultural statistics 2008. Bangladesh Bureau of Statistics, Government of the People's Republic of Bangladesh, Dhaka

BGS, DPHE (2001) Arsenic contamination of groundwater in Bangladesh. British Geologic Survey, Keyworth

BWPCB (1976) Bangladesh drinking water standard. Bangladesh Water Pollution Control Board, Government of the People's Republic of Bangladesh, Dhaka

Chapman D (1992) Water quality assessment - a guide to use of biota, sediments and water in environmental monitoring. Chapman and Hall, London

Chiacchio U, Librando V, Magazzu G (1997) Monitoring studies of Augusta Bay marine waters. Environ Monit Assess 44:383-390

Chopra SL, Kanwar JS (1980) Analytical agricultural chemistry. Kalyan Publishers, New Delhi

Dalton MG, Upschurch SB (1978) Interpretation of hydrochemical facies by factor analysis. Groundwater 16:228-233

Datta PS, Tyagi SK (1996) Major ion chemistry of ground-water in Delhi area: chemical weathering processes and ground-water flow regime. J Geol Soc India 47(2):179-188

DoE (1997) The environment conservation rules 1997. Government of the People's Republic of Bangladesh, Dhaka

Doneen LD (1964) Notes on water quality in agriculture, water science and engineering. University of California, Davis

FAO (1985) Water quality for agriculture. Food and Agriculture Organization. http://www.fao.org/docrep/003/t0234e/T0234E01. htm\#ch1.4. Accessed 21 Dec 2013

Gaillardet J, Dupré B, Louvat P, Allègre CJ (1999) Global silicate weathering and $\mathrm{CO}_{2}$ consumption rates deduced from the chemistry of large rivers. Chem Geol 159:3-30
Gibbs RJ (1970) Mechanisms controlling world water chemistry. Science 17:1088-1090

Golterman HL (1971) Methods for chemical analysis for fresh waters. Blackwell Scientific Publication, Oxford

Gupta SK (1983) Variations of water table in Yamuna drainage basin of Haryana-implications and management strategies. Paper presented at the Seminar on Strategies for Irrigation Water Management, Patna

Gupta SK, Gupta IC (1987) Management of saline soils and waters. Oxford and IBH Publishing Company, New Delhi

Gupta AK, Gupta SK, Patil RS (2005) Statistical analyses of coastal water quality for a port and harbour region in India. Environ Monit Assess 102:179-200

Helena B, Pardo R, Vega M, Barrado E, Fernández JM, Fernández L (2000) Temporal evolution of groundwater composition in an alluvial aquifer (Pisuerga River, Spain) by principal component analysis. Water Res 34(3):807-816

Hussain I, Hussain J (2004) Evaluation of irrigation water quality of the village situated near river Kothari, Rajasthan (India). Pollut Res 23:561-564

Islam MS, Shamsad SZKM (2009) Assessment of irrigation water quality of Bogra district in Bangladesh. Bangladesh J Agric Res 34:597-608

Joshi DM, Kuman A, Agrawal N (2009) Assessment of the irrigation water quality of River Ganga in Haridwar district. Indian J Chem 2(2):285-292

Kehew AE (2001) Applied chemical hydrogeology. Prentice Hall, New Jersey

Kelley WP (1963) Use of saline irrigation water. Soil Sci 95:355-391

Kucuksezgin F (1996) Multivariate analysis of water quality parameters in Izmir Bay, Eastern Aegean. Toxicol Environ Chem 55:135-144

Liu C, Lin K, Kuo Y (2003) Application of factor analysis in the assessment of groundwater quality in a blackfoot disease area in Taiwan. Sci Total Environ 313:77-89

Matthess G (1982) The properties of ground water. Wiley, New York

Michael AM (1992) Irrigation theory and practices. Vikash Publishing House Pvt. Ltd., New Delhi

Morales MM, Marti P, Liopis A, Campos L, Sagrado S (1999) An environmental study by factor analysis of surface sea waters in the gulf of Valencia (Western Mediterranean). Anal Chim Acta 394(1):109-117

MPO (1987) Groundwater resources of Bangladesh. Master Plan Organization, Government of the People's Republic of Bangladesh, Dhaka

Mridha MAK, Rashid MH, Talukder KH (1996) Quality of groundwater for irrigation in Natore district. Bangladesh J Agric Res 21:15-30

Obiefuna GI, Sheriff A (2011) Assessment of shallow ground water quality of Pindiga Gombe Area, Yola Area, NE, Nigeria for irrigation and domestic purposes. Res $\mathrm{J}$ Environ Earth Sci 3(2):131-141

Piper AM (1944) A graphic procedure in geochemical interpretation of water analysis. Am Geophys Union Trans 25:914-923

Praus P (2005) Water quality assessment using SVD based principal component analysis of hydrological data. Water SA 31(4):417-422

Punmia BC, Lal PBB (1981) Irrigation and water power engineering. Standard Publishers Distributors, New Delhi

Quddus KG, Zaman MW (1996) Irrigation water quality in some selected villages of Meherpur in Bangladesh. J Agric Sci 23(1):51-57

Raghunath HM (1987) Groundwater. Wiley Eastern, New Delhi

Rahman MATMT, Majumder RK, Rahman SH, Halim MA (2011) Sources of deep groundwater salinity in the southwestern zone of Bangladesh. Environ Earth Sci 63:363-373 
Rahman MATMT, Rahman SH, Majumder RK (2012) Groundwater quality for irrigation of deep aquifer in southwestern zone of Bangladesh. Songklanakarin J Sci Technol 34(3):345-352

Raihan F, Alam JB (2008) Assessment of groundwater quality in Sunamganj Bangladesh. Iranian $\mathrm{J}$ Environ Health Sci Eng 6(3): $155-166$

Richards LA (US Salinity Laboratory) (1954) Diagnosis and improvement of saline and alkaline soils, US Department of Agriculture hand book, pp 60

Robinove CJ, Longfort RH, Brook JW (1958) Saline water resource of North Dakota. US Geological Survey, Virginia

Rowe DR, Magid IMA (1995) Handbook of wastewater reclamation and reuse. CRC Press, Florida

Sami K (1992) Recharge mechanisms and geochemical processes in a semi-arid sedimentary basin, Eastern Cape, South Africa. J Hydrol 139:27-48

Sarin MM, Krishnaswamy S, Dilli K, Somayajulu BLK, Moore WS (1989) Major-ion chemistry of the Ganga-Brahmaputra river system: weathering processes and fluxes to the Bay of Bengal. Geochim Cosmochim Acta 53:997-1009

Sarkar AA, Hassan AA (2006) Water quality assessment of a groundwater basin in Bangladesh for irrigation use. Pak J Biol Sci 9(9):1677-1684

Sawyer CN, McCarty PL (1967) Chemistry for sanitary engineers. McGraw-Hill, New York

Shahidullah SM, Hakim MA, Alam MS, Shansuddoha ATM (2000) Assessment of groundwater quality in a selected area of Bangladesh. Pak J Biol Sci 3(2):246-249

Shirazi SM, Akib S, Salman FA, Alengaram UJ, Jameel M (2010) Agroecological aspects of groundwater utilization: a case study. Sci Res Essays 5:2786-2795

Singh AK, Hasnain S (1999) Environmental geochemistry of Damodar river basin, East coast of India. Environ Geol 37(1):124-136

Sivasubramanian P, Balasubramanian N, Soundranayagam JP, Chandrasekar N (2013) Hydrochemical characteristics of coastal aquifers of Kadaladi, Ramanathapuram District, Tamilnadu, India. Appl Water Sci 3:603-612

Sood A, Verma VK, Thomas A, Sharma PK, Brar JS (1998) Assessment and management of underground water quality in Talwandi Sabo Teltsil of Bathinda district (Punjab). J Indian Soc Soil Sci 46:421-426

Stallard RF, Edmond JM (1983) Geochemistry of the Amazon: 2. The influence of the geology and weathering environment on dissolved load. J Geophys Res 88:9671-9688

Subramani T, Elango L, Damodarasamy SR (2005) Groundwater quality and its suitability for drinking and agricultural use in Chithar River Basin, Tamil Nadu, India. Environ Geol 47:1099-1110
Sultana N, Haque MA, Elahi SF (2009) Evaluation of surface irrigation water quality in Muktagacha upazila of Bangladesh. Songklanakarin J Sci Technol 31:229-235

Talukder MSU, Shirazi SM, Paul UK (1998) Suitability of groundwater for irrigation at Karimganj Upazila Kishoreganj. Progress Agric 9(1-2):107-112

Talukder MSU, Shirazi SM, Niazuddin M, Ghosh AK (1999) Groundwater quality and its impact on soil and crop, Bangladesh. J Agric Sci 26(3):153-160

Taylor SR, McLennan SM (1985) The continental crust: its composition and evolution. Blackwell, London

Todd DK (1980) Groundwater hydrology. Wiley, New York

UCCC (1974) Guidelines for interpretations of water quality for irrigation. University of California Committee of Consultants, California

UNDP (1982) Groundwater survey: the hydrogeological conditions of Bangladesh. UNDP, New York

Unmesh CP, Sanjay KS, Prasant R, Binod BN, Dinabandhu B (2006) Application of factor and cluster analysis for characterization of river and estuarine water systems - a case study: Mahanadi River (India). J Hydrol 331(3-4):434-445

Vega M, Pardo R, Barrado E, Deban L (1998) Assessment of seasonal and polluting effects on the quality of river water by exploratory data analysis. Water Res 32(12):3581-3592

WARPO (2000) National water management plan project, draft development strategy. Water Resources Planning Organization, Government of the People's Republic of Bangladesh, Dhaka

Wen X, Wu Y, Su J, Zhang Y, Liu F (2005) Hydrochemical characteristics and salinity of groundwater in the Ejina Basin, Northwestern China. Environ Geol 48:665-675

Wilcox LV (1948) The quality of water for irrigation use. US Department of Agriculture, Washington, DC

Wilcox LV (1955) Classification and use of irrigation water. US Department of Agriculture, Washington, DC

World Bank (2005) Towards a more effective operational response: arsenic contamination of groundwater in south and East Asian countries. The World Bank, Washington, DC

Zahid A, Hassan MQ, Balke KD, Flegr M, Clark DW (2008) Groundwater chemistry and occurrence of arsenic in the Meghna floodplain aquifer, southeastern Bangladesh. Environ Geol 54:1247-1260

Zeng X, Rasmussen TC (2005) Multivariate statistical characterization of water quality in Lake Lanier, Georgia, USA. J Environ Qual 34:1980-1991

Zhang G, Deng W, Yang YS, Salama RB (2007) Evolution study of a regional groundwater system using hydrochemistry and stable isotopes in Songnen Plain, northeast China. Hydrol Process 21:1055-1065 